\title{
THE TRANSLATION OF INDONESIAN PASSIVE VOICE INTO ENGLISH IN THE NOVEL 9 SUMMERS 10 AUTUMNS TRANSLATED BY MAGGIE TJIOJAKIN
}

\author{
Desi Amalia \\ Andang Saehu \\ Irman Nurhapitudin \\ State Islamic University Sunan Gunung Djati
}

\begin{abstract}
The study is conducted based on qualitative research design with descriptive analysis. The data are 67 passive construction in Indonesian and English as used in the novel "9 Summers 10 Autumns (Dari Kota Apel ke The Big Apple)" and translated into "9 Summers 10 Autumns (From the City of Apples to the Big Apple). The research problems are the first what are the corresponding equivalents of Indonesian passive in English as used in the Novel 9 Summers 10 Autumns and its translation, the second what is the translation method or procedure that used in the process of passive voice translation. The steps and procedures of discovering the answer to the both of research problems are shown under the discussion of research method which includes: (1) the data source, (2) method and technique of collecting the data consisting of observation method and note-taking technique; (3) method and technique of analyzing the data. The results of the study show that among the passive in Indonesian which can be identified in SL, most are marked by prefix di- (prefix di- + verb base) and (prefix di+ verb base + suffix -kan, -i) which are also translated into passive in English (be+past participle ) with four types namely to infinitive translation, by agent translation (stated and implied) and the rest translated into active. This clearly reveals that some passives in SL are retained, namely translated into passive in English and some others are translated into actives. Second, from the whole data analysis the researcher found 4 types of translation methods or procedures used in the passive translation, namely literal translation, transposition, modulation, and adaptation.
\end{abstract}

Keywords: Passive voice, translation procedures, novel

\section{INTRODUCTION}

Language and communication have the close relationship each other due to the people communicate with others surely, they use it as the instrument of communication. Communication is the process of delivering information between individual or groups through the symbol system, sign or the common behavior. Catford (1965: 1) argues "Language is a pattern of human behavior and it is a way, perhaps the most important way, in which human beings interact in social situations". So that, all human as the social person can interact with others in their daily life by using language. It is dynamic and it does not separate from any possibilities of changes.

As the communication tools, language can be assessed internally or externally. Internal study is the study of intern structure of the language, such as phonology, morphology, syntax, and semantics, meanwhile the external study is the study which is done to the external factors of the language that associated with the 
using of language by the speakers in the community. From the intrinsic or linguistic point of view the attempt to create a model of translation process is believed to be inherently interesting and valuable as a means for testing theory and for investigating language use. From a practical viewpoint, it is clear that in a rapidly changing world in which knowledge is evolving and expanding at an unprecedented rate, information transfer is coming to immensely depend more and more on efficient and effective translation.

Nida and Taber (1969: 12) point out that translating consists of reproducing in the receptor language the closest natural equivalent of the source language message, first in terms of meaning and secondly in terms of style. Argue with this statement, it can be obviously seen that meaning of a source language text must be replaced by the closest natural equivalent in the target language. In line with this, the style which is closely related to choose of words and sense of expressing ideas becomes very important in the rendering of a SL into the TL.

Therefore, the translator as the person who plays an important role in conveying the message of SL should not only master the language but also be competent in finding the closest natural equivalent of TL lexical items. It means that the translator must be able to produce a stylistically natural TL, which necessarily involves change of the form.

The change of structure from one form to another is not uncommon in translation. To gain naturalness, passive constructions will frequently need to be translated with active constructions or vice versa. The phenomenon is often happened in the Indonesian - English translation, because Indonesian has the particular characteristic in the word order. According to Sneddon (1996: 254) the passive construction is more often used in Indonesian than in English. Sometimes, the passive sentence in Indonesia sounds strange when translated into English. For example, when Indonesian people would like to help others, they usually say, "Bisa dibantu?" (Literal translation: "Can be helped?"). Idiomatically, it is translated into, "Can I help you?". In English, the speaker is mentioned by "I" whereas in the Indonesian, it is not necessarily stated, but implied.

According to Sneddon (1996: 241) clause which have an object are called transitive clauses and verbs which occur in these clauses are called transitive verb. A transitive clause is the one that can be changed into passive minimally consists of a subject, a predicate and an object, for example:

\section{(1) Ali menjual mobilnya}

Ali sold his car.

In English most passive construction are formed with the auxiliary be followed by verb (past participle), for example:

\section{(2) The book is bought by Ana}

In that example, the subject is the patient namely "The book" followed by "be + Verb" namely "is bought. Whereas Indonesian passive constructions are mostly marked by prefix di + base verb, for example:

\section{(3) Buku itu dibeli oleh Ana}

The structure of a passive clause can be described in the form of corresponding active. It is suggested where a passive translation would sound unnatural. This is because of the different characteristics of the Indonesian language and English. The Indonesian language merely focus on the result of the action. For example, Saya dijemput olehnya, which literally I was met by him (Sneddon, 1996:247). The 
sentence I was met by him sounds awkward in English. Thus. When using this expression, the sentence will sound more natural in English if it is changed into "He picks me up". So that, the active construction is more common in English since the focus of attention is the actor that conducting action.

From the explanation above, the researcher is so interested in and curious about investigating how Indonesian passive construction in the Novel "9 Summers 10 Autumns, Dari Kota Apel ke The Big Apple"and its translation " 9 Summers 10 Autumns From the City of Apples to the Big Apple"were exist and changed into another forms. The novel is published by Gramedia Pustaka Utama, and first launched in Indonesia, in October 2011. The use of passive voice in the Indonesian version is interesting to be discussed. It is found that there are some examples of passive construction which seem to unretained and are indeed worth analyzing.

Some related thesis to support this research are : the first study was conducted by Sari (2009) on "An Analysis of Translation Procedures of Translating Computer Term in Andrew S. Tanenbaum 3rd Computer Networks Into Bahasa Indonesia, conclude that translation procedures from the data analysis are 84 cases containing 4 procedures, there are 39 cases of borrowing or $46 \%, 24$ cases of calque or $29 \%, 16$ cases of literal translation or $19 \%$, and 5 cases of transposition or $6 \%$.

The second study was also delivered by Rifki (2006) on "Comparison of Passive Voice Between English and Arabic (Analysis on The Last Chapter of English Translation Qur'an)" reveals that the passive forms in Arabic consists of simple presents and simple past tense, meanwhile the form of passive voice in English consists of simple present (present tense, present perfect tense, and present future tense), the passive forms of simple past (past tense and past perfect tense). Further, the data shows that both similarities and differences can be divided into six structure of words, these are the structure of word implication, placing of words, changing of words, changing of words position, arrangement of words, and the meaning of words.

The last study was done by Sadiyani (2009) on "The Translation of Indonesian Passive Voice into English With Reference to Bawang Merah dan Bawang Putih and Its Translation Miss Onion and Miss Garlic". The findings reveal that some passives in source language are retained, namely translated into passives in English and some others are translated into actives.

There are the differences between these analyses with previous analysis although both of them have the same main focus on passive voice translation. This analysis focuses on the method of translation that the translator used to translate the passive sentence in SL into TL so that the translation sounds natural based on the meaning. Thus, the researcher decided to analyze it and becomes challenge for well doing. In this research, the researcher limits that problem with the following questions:

1. What are the corresponding equivalents of Indonesian passive contructions in English as used in the novel "9 Summers 10 Autumns" and Its translation?

2. What is the method of translation that used in the Indonesian passive constructions (SL) and their translation equivalents into English (TL)?

Based on the statement of problem above, the writer takes some purposes of research, such as: 
1. To identify the corresponding equivalents of Indonesian passive constructions in English as used in the novel and its translation.

2. To explain more detail about the method of translation when translating SL into TL so that the TL sounds natural.

\section{Discussion}

This chapter deals with the analysis and discussion of the translation of Indonesian passive voice constructions into English with reference to the novel "9 Summers 10 Autumns" and its translation based on Sneddon and Alwis's theories about passive voice construction as well as, the method of translation by Vinay and Dalbarnet . In congruent with the research problems, this chapter consists of two parts, they are the exposure of equivalents of Indonesian Passive Voice (SL) in its translation in English categories (TL) and those methods of translation. From both of discussions, there were 67 passive sentences in Indonesian will be analyzed.

\subsection{Corresponding the Equivalents of Indonesian Passive Voice in English}

Based on the overall data for this study, there are 67 passive sentences in Indonesia (SL) and the equivalents in English (TL) that found by the researcher. In analyzing the categories of those equivalences the writer used Alwi's theory to divide the passive sentences. Based on Alwi (1998 : 345-347) in their book Tata Bahasa Buku Bahasa Indonesia figure out passivization in Indonesia can be done in two ways. The first and the most common way of forming passive constructions in Indonesia is using verb base attached with prefix di-, (Prefix di- + verb base + suffix, and the second way of forming passive in Indonesian is with verb without prefix di-.

Then, the identified passive voices in the SL which began with prefix di- + verb base and prefix di-+ verb base+ suffix-kan and its equivalent in English can further be classified into four types : (1) Indonesian passive voice into English in the form of "to infinitive" ; (2) Indonesian passive voice into English in the form of "by agent"; (3) Indonesian passive voice into English in the form of "by implied"; (4) Indonesian passive voice into English in the form of "active voice".

\subsubsection{To Infinitive Construction of Passive Voice}

There are 4 passive constructions in Indonesian which are formed with prefix di- + verb base + suffix (-kan, ) and prefix di- + verb base as well as their equivalents are formed with : $\mathrm{Be}+$ Past participle + to infinitive phrase. The four passive voices in the SL and their equivalents in the TL as follows : 
Table 2.1. Data Showing Passive Constructions in Indonesian (SL) and Their Corresponding

Passive Equivalents with " to infinitive " in English (TL)

\begin{tabular}{|l|l|l|l|}
\hline & $\begin{array}{c}\text { Passive Voice With } \\
\text { Prefix di- and ter- in SL }\end{array}$ & $\begin{array}{l}\text { Translation of Passive Voice in } \\
\text { TL }\end{array}$ & $\begin{array}{l}\text { Equival } \\
\text { ents } \\
\text { Forms } \\
\text { in TL }\end{array}$ \\
\hline 1 & $\begin{array}{l}\text { Aku } \\
\text { untuk selalu bersyukur } \\
\text { dan membahagiakan } \\
\text { saudara-saudaraku. }\end{array}$ & $\begin{array}{l}\frac{\text { dingatkan reminded once again to }}{\text { to }} \\
\text { always count my blessings and } \\
\text { (P.122/127) sisters happy. }\end{array}$ & $\begin{array}{l}\text { Be past } \\
\text { participl } \\
\text { e to } \\
\text { infinitive }\end{array}$ \\
\hline
\end{tabular}

The identified passive voices "diingatkan" in the SL "Aku diingatkan lagi untuk selalu bersyukur dan membahagiakan saudara-saudaraku", which began with prefix di- + verb base + suffix -kan, which are equivalently translated into : $\mathrm{Be}+$ past participle + to infinitive in the TL and classified as the type of present tense passive pattern (Alexander, 1994 :246) "I am reminded once again to always count...". I as Subject, am as Singular Auxiliary, reminded as Past Participle, to always count as to infinitive. This translation process further reveals that the translator is adopting literal translation procedure in translating passive constructions in Indonesian into English. It also shows the significance to effectively and efficiently translate a source language into a target language on the basis of the nature of equivalents, as well as the direct transfer of a SL text into a grammatically and idiomatically appropriate TL text in which the translator's task is limited to observing the adherence to the linguistics of the TL (Vinay and Dalbarnet). By translating this passive construction in the SL into passive construction in English (TL), the meaning is most fully transferred, there is no specific change.

\subsubsection{By Agent Construction of Passive Voice}

There are other passive constructions in Indonesian which are formed with Prefix di-verb base + suffix (-lah, -nya, -i) and their equivalents are formed with : $\mathrm{Be}+$ Past participle + by agent phrase by (stated). The eight passive voices in the $\mathrm{SL}$ and their equivalents in TL are as below: 
Table 2.2 Data Showing Passive Constructions in Indonesian (SL) and Their Corresponding Passive Equivalents with "by agent" in English (TL)

\begin{tabular}{|l|l|l|l|}
\hline & $\begin{array}{l}\text { Passive Voice With Prefix } \\
\text { di- and ter- in SL }\end{array}$ & $\begin{array}{c}\text { Translation of Passive } \\
\text { Voice in TL }\end{array}$ & $\begin{array}{l}\text { Equivalents } \\
\text { Forms in TL }\end{array}$ \\
\hline 1 & $\begin{array}{l}\text { Seumur hidup, baru pertama } \\
\text { kali aku merasakan } \\
\text { bagaimana } \\
\text { dihantam oleh tangan } \\
\text { manusia }\end{array}$ & $\begin{array}{l}\text { In my entire life, I have never } \\
\text { been hit by another human } \\
\text { being }\end{array}$ & $\begin{array}{l}\text { Be + Past } \\
\text { Participle + }\end{array}$ \\
\hline
\end{tabular}

The identified passive voices "dihantam" in the SL "Seumur hidup, baru pertama kali aku merasakan bagaimana wajahku dihantam oleh tangan manusia" which began with prefix di-+ verb base + agent phrase "oleh" or prefix di- + verb base + suffix + agent phrase "oleh" is straightforwardly translated into : $\mathrm{Be}+$ past participle + agent "by" in the TL and classified as the type of present perfect tense passive pattern (Alexander, 1994 :246) "In my entire life, I have never been hit by another human being". I as Subject, have never been as Plural Auxiliary, hit as Past Participle, by another human being as agent "by". The forms of those passive voice and its equivalent are in fact the most basic, common and rudimentary passive voices which are not sparingly used either in speech or writing (Sneddon, 1998). They are therefore analyzed to be close equivalents in syntactical and phrasal forms in the sense they can most appropriately function as carriers of original meaning.

\subsubsection{By Implied Construction of Passive Voice}

There are some more passive constructions in Indonesian which are formed with Prefix di-verb base + suffix (-kan, -I, -an, -lah) and Prefix di- + verb base, and their equivalents are formed with : $\mathrm{Be}+$ Past participle + by agent (implied) phrase. The fifteen passive voices in the SL and their equivalents in the TL are as below : 
Table 2.3 Data Showing Passive Constructions in Indonesian (SL) and Their Corresponding Passive Equivalents with "by implied" in English (TL)

\begin{tabular}{|l|l|l|l|}
\hline & \multicolumn{1}{|c|}{$\begin{array}{c}\text { Passive Voice With } \\
\text { Prefix di- and ter- in SL }\end{array}$} & \multicolumn{1}{|c|}{$\begin{array}{l}\text { Translation of Passive } \\
\text { Voice in TL }\end{array}$} & $\begin{array}{l}\text { Equivalents } \\
\text { Forms in TL }\end{array}$ \\
\hline 1 & $\begin{array}{l}\text { Aku disuguhi sebuah } \\
\text { kemewahan }\end{array}$ & $\begin{array}{l}\text { I was served with a dream of } \\
\text { richness }\end{array}$ & $\begin{array}{l}\text { Be + Past } \\
\text { Participle + } \\
\text { (agent by } \\
\text { implied) }\end{array}$ \\
\hline
\end{tabular}

The identified passive voices "disuguhi" in the SL "Aku disuguhi sebuah kemewahan" which began with prefix di-+ verb base + suffix $-\mathrm{i}$ is straightforwardly translated into : Be + past participle + (agent phrase implied) it can be optional or also be followed by other necessary phrases or adjunct, in the TL "I was served with a dream of richness" and classified as the type of past tense passive pattern (Alexander, 1994 :246). I as Subject, was as singular Auxiliary, served as Past Participle, with a dream of richness as phrase. The forms of those passive voice and its equivalent are in fact the most basic, common and rudimentary passive voices which are not sparingly used either in speech or writing (Sneddon, 1998). They are therefore analyzed to be close equivalents in syntactical and phrasal forms in the sense they can most appropriately function as carriers of original meaning.

\subsubsection{Active Construction of Passive Voice}

There are 40 passive constructions in Indonesian which are formed with : Prefix di- + Verb base + suffix (-lah, -kan, -I, -nya) and Prefix di- +verb base their equivalents all formed with : $\mathrm{S}+\mathrm{P}+\mathrm{O}$ (passive constructions in $\mathrm{SL}$ are changed into active voices in the TL). There are as below.

Table 2.4 Data Showing Passive Constructions in Indonesian (SL) and Their Corresponding Passive Equivalents with "Active" in English (TL)

\begin{tabular}{|l|l|l|l|}
\hline & $\begin{array}{c}\text { Passive Voice With } \\
\text { Prefix di- and ter- in SL }\end{array}$ & \multicolumn{1}{|c|}{$\begin{array}{c}\text { Translation of Passive } \\
\text { Voice in TL }\end{array}$} & $\begin{array}{l}\text { Equivalents } \\
\text { Forms in TL }\end{array}$ \\
\hline 1 & $\begin{array}{l}\text { Ranjang ini ditempatkan } \\
\text { di sudut ruang tamu kami, } \\
\text { di dekat pintu dapur, di } \\
\text { depan kamr orang tuaku }\end{array}$ & $\begin{array}{l}\text { He placed in a corner of } \\
\text { the living room, near the } \\
\text { kithen door, in front of my } \\
\text { parent's bedroom }\end{array}$ & $\begin{array}{l}\text { S+P+O } \\
\text { (active) }\end{array}$ \\
\hline
\end{tabular}

The identified passive voices "ditempatkan" in the SL "Ranjang ini ditempatkan di sudut ruang tamu kami, di dekat pintu dapur, di depan kamr orang tuaku" which began with prefix di-+ verb base + suffix -kan is straightforwardly translated 
into active : $\mathrm{S}+\mathrm{V}+\mathrm{O}$ (active), in the TL "He placed it in a corner of the living room, near the kithen door, in front of my parent's bedroom", and classified as the type of past tense. He as Subject, placed as verb (past tenses), in a corner of the living room, near the kithen door, in front of my parent's bedroom as Complement. The conversion passive construction in Indonesia into active construction in English is certainly grounded by the selection of the most appropriate syntactical structures as well as the most natural carriers of the original meanings. This is due to the fact that the passive construction in the SL will sound much more natural if they are translated into active construction in the TL, and if they are also to be translated into passive in English, they will of course sound unnatural (Sneddon, 1996).

\subsection{The Method of Translation Used in Indonesian Passive Voice into English}

Translation consists of studying the lexicon, grammatical strucrure, communication situation, and cultural context of the source language, analyzing it in order to determine its meaning, and then restructuring this same meaning using the lexicon and grammatical structure which are appropriate in the target language and its cultural context. In translating the Indonesian passive voice the translator surely used the proper method based on the context to get the meaning as natural as possible.

In analyzing the method of translation in this Indonesian passive voice and its equivalence in English, the researcher used Vinay and Dalbarnet's theory to decide what method that has been done by the translator. Vinay and Dalbarnet in their article "A Methodology for Translation" in Ventuni (2000: 84-93) propose seven procedures of translations. Those seven procedures are borrowing, calque, literal translation, transposition, modulation, equivalence, and adaptation. In the 67 passive sentences and its equivalents in English, the researcher found mostly 4 methods that dominate the process of translation, they are literal, transposition, modulation, and adaptation. There are 23 sentences that translated as literal, 18 sentences translated as transposition, 16 sentences translated as modulation and 10 sentences translated as adaptation.

\subsubsection{Literal Translation}

Larson (1998) assert that literal translation procedure basically relies on wordfor-word, phrase-for-phrase, and clause-for-clause or even sentence-for-sentence translation equivalence. From the 67 passive sentences, there are 23 sentences that translated using literal.

(1) SL : Kami diminta untuk merngolah data untuk departemen media

TL : We were asked to process data from Media department

In data (1), the process of translation is done by word for word and straightforwardly no change or shift. In the SL the word diminta translated into original passive voice formula (were + verb participle) were asked that has the original meaning in the TL or English (meminta in English is ask or beg ). The translation product in TL is past tenses form because the story 
happened in the past or retell situation. Its equivalent to infinitive in TL literally translated word by word too, namely untuk translated into "to"and merngolah data translated into "process data"

\subsubsection{Transposition}

From the 67 passive sentences, there are 18 sentences that translated using transposition procedure.

(2) SL : Lampu itu hanya kami nyalakan kalau mau masuk dapur saja

TL : We were only allowed to turn it on whenever we had to enter the kitchen at night.

In the data (2) there is a change in SL grammatically without change the message of the sentence in TL. In the SL the word "lampu" is as subject, hanya kami nyalakan as verb clause, "kalau mau masuk dapur saja" as complement, but in the TL the sentence change to be more effective, namely We place as subject which in the SL previously placed in verb clause, were only allowed to turn it on is the form of passive from SL "nyalakan". Based on the data if the SL translated literal, it will sound unnatural. Even there is a change in the level of grammatical, the meaning in the SL keep delivering in the TL.

\subsubsection{Modulation}

From the 67 passive sentences, there are 16 sentemces that translated using modulation procedure.

(3) SL : Di antara TV tua 14 inci, DVD player, dan tape sony, ruangan studio ini dihiasi satu topeng kulit dari venesia.

TL : Among an old 14-inch TV, DVD player and Sony radiotape, the studion is enriched by a Venetian mask made out of leather.

In the data (3) there is a meaning shift from the sentence. In the SL, the identified passive voice is dihiasi and translated into TL "is enriched by". Based on the data, dihiasi literally will be translated to decorated, but the translator using word enriched to explore the meaning, becauase in Indonesia it means "memperkaya", from the sentence it shows that the translator want to make the sense of sentence sounds more natural and shows the situation in the studion greater and ellegant. 


\subsubsection{ADAPTATION}

From the 67 passive sentences, there are 10 sentemces that translated using adaptation procedure.

(4) SL : Setiap pagi, sekitar pukul 05.30 aku berangkat diantar Bapak dengan truk angkutan barangnya

TL : Every morning, at 15.30 am, my father would take me to work on his truck

In the data (4) the process of translation adopted is adaptation because the situation being referred to by the source language (SL) message but unknown in the target language (TL) culture. In the SL, the identified passive voice is "diantar" and translated into TL as "take me to work". In this case a translator should create a new situation that can be considered being aquivalent.

\section{Conclusions}

Based on what already been discussed in discussion, the researcher formulated the following conclusions as of the result of the data analysis, those were:

1. The equivalent of Indonesian passive translation into English can be specified : (1) There are 4 passive sentences which are marked with : Prefix di- + verb base + suffix (-kan) are equivalently translated with : Be + Past participle + to infinitive phrase; (2) There are 8 passive voices which are formed with : Prefix di- + verb base + suffix $(-\mathrm{i})$ and Prefix di- + verb base were equivalently translated with : $\mathrm{Be}+$ Past Participle + agent phrase by (stated); (3) and there are 15 another passives which are formed with Prefix di- + verb base + suffix (kan, -lah, -i ) and Prefix di- +verb base are eqivalently translated with : $\mathrm{Be}+$ Past Participle (implied agent phrase ); (4) and there are 40 more passive voices which are formed with Prefix di- + Verb base + suffix (-kan, -nya, -i ) and Prefix di- + verb base are equivalently translated into active with the common pattern $\mathrm{S}+\mathrm{P}+\mathrm{O}$ (complement).

2. The method or procedures of translation that used to make the translation of Indonesian passive voice into English sounds natural dominated by literal translation, transposition, modulation, and adaptation.

\section{References}

Bowen, Glenn A. 2009. Document Analysis as a Qualitative Reseacrh Method. [online]. Qualitative Research Journal, Vol. 9, No. 2, 2009: doi: 10.3316/QRJ0902027.Availability:<http://search.informit.com.au/docume nt Summary;dn=252446162410248;res=IELHSS > ISSN: 1443-9883. [cited 15 Jun 16$]$.

Catford, J.C. 1965. A Linguistic Theory of Translation. London: Oxford University Press 
Creswell, John W. 1998. Qualitative Inquiry and Research Design. Thousand Oaks, CA: SAGE production.

Djuharie, Otong Setaiawan. 2004. Teknik dan Panduan Menerjemahkan Bahasa Inggris-Bahasa Indonesia. Bandung: CV. Yrama Widya

Echols, John, and Sahadily, Hasan.1992. Kamus Inggris-Indonesia. Jakarta: PT. Gramedia

Hatim, Basil and Jeremy Munday. 2004. Translation: An Advanced Resource Book. London and New York: Routledge

Hornby, AS. 2000 Oxford Advanced Learners Dictionary of Current English: Oxford University Press

Larson, M.L 1998. Meaning Based Translation. A Guide to Cross-Language Equivalence. Second Edition. New York: University Press of America

Newmark, Peter. 1998. A Textbook of Translation. London: Prentice Hall.

Nida, E.A. and Charles R. Tiber. 1969. The Theory and Practice of Translation. Leiden: E.J.Brill

Sadiyani, Ni Wayan. 2011. The Translation of Indonesian Passive Voice Into English With Reference To Bawang Merah dan Bawang Putih and Its Translation Miss Onion and Miss Garlic. Thesis.Denpasar: Master's Degree Program Study Program of LinguisticsPostgraduate Program Udayana University.

Vinuti, Lawrence.2000.The Translation Studies Reader.London : Routledge

Vinay, Jean-Poul and Darbelnet, Jean. 2000. A methodology for Translation. In Vinuti, Lawrence (Ed).The Translation Studies Reader. (pp. 84-93): London: Routledge. 